\title{
IMPROVING THE QUALITY OF LEARNING ENVIRONMENT THROUGH PROCESS ORIENTED GUIDED INQUIRY LEARNING (POGIL) ENRICHED BY SOCIOSCIENTIFIC ISSUES (SSI) ON CHEMISTRY SOLUTION
}

\author{
Sri Rahayu ${ }^{1 *}$, Fitri Aldresti ${ }^{1}$ and Fauziatul Fajaroh ${ }^{1}$ \\ ${ }^{1}$ Chemistry Department, Faculty of Mathematics \& Science, Universitas Negeri Malang, Indonesia
}

\begin{abstract}
The main goal of science/chemistry education is achieving scientific literacy for all students. For this purpose, there are some competencies and skills need to be developed in a supporting learning environment. This study aimed to examine students' perceptions on learning environment in the POGIL -SSI instruction in the chemistry solution topic. A quasi experiment with posttest only was designed. The subject consisted of 85 high school students who divided into Experiment group $1(\mathrm{~N}=28)$, Experiment group $2(\mathrm{~N}=29)$, and Contol group $(\mathrm{N}=28)$ and were teached using POGIL-SSI, POGIL, and conventional instructions, respectively. Data of students' perceptions was collected using WIHIC instrument (Cronbach Apha $=0.943$ ) and analized using One-Way ANOVA and Post-Hoc LSD test. The result shows that there is a significant difference on students' perceptions among the three groups. However, Experiment group 1 is not significantly different from Experiment gorup 2.
\end{abstract}

Keywords: Process Oriented Guided Inquiry Learning (POGIL), Socioscientific Issues (SSI), Learning Environment.

\section{Introduction}

One effort to create a positive and productive learning experience in the classroom is to provide an effective learning environment for students (Slavin, 2006: 351). Learning environment is an important factor in learning, because it can affect student attitudes and achievement (Fraser, 1999). Various studies on the learning environment have been conducted by researchers in various countries and various fields of study. The achievement of Indonesian students' learning at international level is reflected in the PISA test results conducted since 2000. The result of PISA's last evaluation in 2015, Indonesia ranks 64th (Rahayu, 2015). This sequence shows that students' learning achievement including students' literacy ability is low. One possible cause is science learning process in Indonesia is still dominated by lecture methods. This is supported by the results of research Rahmat (2010) on the study of methods of learning Biology in schools that shows that the method used by teachers in teaching from one subject to another subject less innovative and inclined to teacher-centered by using lecture method. The reason teachers still use lecture methods based on the results of questionnaires given by Rahmat (2010) include: 1) to overcome the limitations of learning time; 2) to be easy to manage classroom; 3 ) to be easy to implement; 4) have speaking skills; and 5) teachers' attention is not divided. The application of this lecture method has an impact on the students' ineffective learning environment because students tend to be passive and rigid (Taylor and Teddlie, 1992). This is supported by the research results by Acat \& Donmez (2009) which states that teacher-centered instruction gives a worse effect on students' learning environments when learning about science and technology.

It requires a student-centered learning approach that can provide a better learning environment for students so that they can learn better and have scientific literacy as their provision to face the globalization era of the $21 \mathrm{st}$ century (Rahayu, 2017). Because as we know that along with the development of the era in the 21 st century, many problems that arise in society caused by the development of science and technology. These problems 
require the settlement of a society with good literacy. People who are science literate are those who have the ability of science and are able to apply their understanding to solve societal / social, environmental and moral issues of science. To achieve that required various skills such as argumentation skills, critical thinking and problem solving. Therefore, the ability of science literacy to be very important to be taught to students in school and become the main goal in science learning (Rahayu, 2017).

In this research, the selected learning approach was inquiry approach with Process Oriented Guided Inquiry Leaning (POGIL) model. This model was chosen because POGIL was developed not only to help students understand content but also the process skills. In its implementation POGIL used study groups, guided discovery activities, problem solving, questions to train critical and analytical thinking, reporting, metacognition and personal responsibility (Hanson, 2006) reflected in the learning stages of POGIL. The five stages of POGIL were orientation, exploration, concept formation, application and closure. The POGIL model was then enriched with socio-scientific issue (SSI) as a learning context. The use of SSI in POGIL was based on suggestions from previous researchers, one of which was Eastwood et al. (2013), stating that there was a need for an approach that integrated the scientific and explicit and explicit social problems, so that SSI could be used to develop students' scientific views of a phenomenon. Therefore, this study aims to determine students' perceptions of the learning environment amongst students who were taught by POGIL enriched with SSI, by POGIL only and by conventional method of learning.

\section{Theoretical Framework}

\section{Learning Environment}

Learning environment is defined both as a space of either closed or open spaces and also be defined as social, psychological and pedagogical contexts that may affect learning, learning achievement and student attitudes (Abdullah et al, 2013). The definition is based on two major components of the learning environment according to Fraser (1994). These two components are physical components and psychosocial components. Physical components include classrooms and teaching and learning facilities both in the classroom and outside the classroom. While the psychosocial components include all interactions that occur between teachers and students, students and students and students with their environment. The concept of a learning environment was initiated by Lewin and Murray in his research on human behavior around the 1930s. Since then many studies have sprung up and become an inspiration for other researchers to develop a questionnaire that is used to find out what students feel about their learning environment. Among the types of questionnaires are Learning Environment Inventory (LEI) (Walberg, 1968), School Level Environment Questionnaire (SLEQ) (Johnson \& Stevens, 2001; Rentoul \& Fraser, 1983), Individualized Classroom Environment Questionnaire (ICEQ) (Fraser, 1990) and Computer Classroom Environment Inventory (CCEI) (Maor \& Fraser, 1996). The learning environment gives different effects to the individual. That is why the learning environment is personal. Any activities and interactions that occur in the classroom will shape the students' construction of their learning environment (Lorsbach \& Basolo, 1998). According to Slavin (2006), efforts to provide an effective learning environment are to prevent bad behavior, use time effectively, and create an atmosphere conducive to discovery activities and activities involving the mind and imagination.

\section{WIHIC}

What Is Happening in This Classroom (WIHIC) is one of the questionnaires used to determine the condition of the learning environment in the classroom. The questionnaire was developed by Fraser, Fisher and McRobbie (1996) by combining the previous version modification questionnaire with additional aspects such as equity. This questionnaire has seven aspects that are measured. These seven aspects include Student Cohesiveness (measuring the extent to which students know, help and support each other in the classroom); Teacher support (measures the extent to which teachers help, be friend to other students, trust and show interest in students about 
their work); Task Orientation (measure the extent to which tasks can be completed and remain on learning materials); Involvement (measure the extent to which students have full attention, participate in discussions, do additional work and enjoy class); Investigation (measures the extent to which instruction emphasizes the skills and processes of discovery and its usefulness for solving problems in investigations); Cooperation (measures the extent to which students work with other students during learning); Equity (measures the extent to which teachers give equal treatment to each student, including giving praise, questions and opportunities to engage in discussion). There are negative and positive questions on every aspect (den Brok et al, 2010; Aldridge et al., 2009).

\section{Process Oriented Guided-Inquiry Learning}

Process Oriented Guided-Inquiry Learning is one of the models based on the inquiry approach. In POGIL, students work in teams with certain designed activities so that students could master the content and science process skills well (Hanson, 2006). This model was developed based on Bransford et al. research on cognitive science. The study concludes that most students can learn very well when they are in a research-based learning environment, that is when students are actively involved in data or analysis activities, discussion activities, working in groups to understand the content or to solve problems, reflect and evaluate to be better and when they interact with teachers as facilitators (Hanson and Moog, 2007). The model has five stages of learning that is orientation, exploration, concept formation, application and closure (Hanson, 2007). Several studies have been conducted to test the effectiveness of applying this model at different levels and subject matter. One such study is the Ruder \& Hunnicutt (2008) study which states that the application of the POGIL model succeeded in significantly changing the learning environment compared to the small classes. Based on these studies, students who were taught by using POGIL were very attentive, so the classroom atmosphere became interactive through group work in the classroom. In this study, students in groups have four roles to maximize group work, ie managers, recorders, presenters and reflectors (Hanson, 2006). The manager is in charge of keeping the team focused on completing the task and ensuring all members participate and understand what is being discussed. The recorder is responsible for recording the results of the discussion and preparing reports. The presenter is in charge of presenting the results of the discussions to the students in the class. While the reflector is responsible for identifying the problem solving strategy and record it.

\section{Socioscientific Issue (SSI)}

Socioscientific problems are a controversial issue in societies relating to science and their resolution involves moral and ethical review (Zeidlers \& Nicols, 2009). They are also defined as socially explicable social problems (Eastwood et al., 2012; Reis \& Galvao, 2009; Sadler, 2004; Sadler et al., 2007; Sadler \& Zeilder, 2004). The sociocultural problem is different from other science problems because it involves many aspects and has many solutions (Yahaya, 2016). The other features of this sociocontific problem are 1) open-ended, because they do not have direct answers right and wrong; 2) poorly structured, because it is controversial in society and has an explanation of various aspects; and 3) is debatable (Sadler \& Zeidler, 2005). Usually to solve this problem is packaged in discussion or dialogue and even debate. Through these activities, students are required to participate actively in developing argumentative skills, the ability to distinguish between science and non-science problems and the ability to recognize reliable evidence and data as the basis of arguments (Zeidlers \& Nicols, 2009). According to Eastwood et al (2012), the provision of socioscientific societies may involve students in the process or activity of discovery in the class. 


\section{Method}

\section{Research Design}

This research ulilized quasy experimental design with posttest only control group design to examine students' perceptions of learning environment. The design involved 3 research groups, namely experimental group I, experimental group II, and control group. The first experimental group was students taught using Processed Guided Inquiry Learning model enriched by socioscientific issues (SSI), the second experimental group was students taught using Process Oriented Guided Inquiry Learning model (POGIL) only, while the control group was students conventionally taught using methods of confirmation and discussion. The study design is illustrated in Table 1 below.

Table 1 Research Design

\begin{tabular}{lcc}
\hline Group & Treatment & Post-test \\
\hline Experiment I & $\mathrm{X}_{1}$ & $\mathrm{O}$ \\
\hline Experiment II & $\mathrm{X}_{2}$ & $\mathrm{O}$ \\
\hline Control & - & $\mathrm{O}$
\end{tabular}

(Adapted from Creswell, 2012)

Note:

O : Observation (post-test of students' perception on learning)

X1 : Learning using POGIL enriched by SSI

X2 : Learning using POGIL

\section{Sample}

Sample of this research was students of class XI of SMA Malang which amounted to 85 students come from three classes and chosen by convenience sampling technique. They were between 16-17 years old and were majoring in science. The three groups were then determined as experimental group I (28 students), experimental group II (29 students) and control group (28 students).

\section{Research Procedure}

The data collection procedure consisted of two stages: the preparation step and the implementation step. At the preparatory step of the research, the researchers prepared the instrument of treatment in the form of syllabus, lesson plans and students worksheets. Then the researchers asked permission at BAKESBANGPOL (National Unity and Politics Board), the local Education Agency and the school involved as the research place. Each experiment group and control group was taught with the same content of chemical solution (salt hydrolysis and buffer solution) and the same learning duration (12 meeting hours @ 45 minutes). After the learning is completed, students filled out the WIHIC questionnaire as a posttest. Implementation step of POGIL enriched by SSI in the experiment class were as follows: 
Table 2 Steps of POGIL enriched by SSI in the topic of Hydrolisis

\begin{tabular}{|c|c|c|}
\hline & Step & Description \\
\hline 1 & Orientation & $\begin{array}{l}\text { - Teachers introduce aspects of nature of science } \\
\text {-Teacher asks students to observe pictures of various salts given in the } \\
\text { worksheet } \\
\text {-Students write and formulate inferences based on information provided by } \\
\text { teachers } \\
\text {-Teacher directs students to make inquiries to make investigation } \\
\text {-The teacher determines the question to be investigated further }\end{array}$ \\
\hline 2 & Exploration & $\begin{array}{l}\text { - Students perform inquiry activities in the form of: observing the three saline } \\
\text { solution images in the worksheets, identifying the similarities of the those } \\
\text { solutions and writing down the reaction that occurs when the salt is } \\
\text { dissolved in water. } \\
\text {-Teacher emphasized the nature of science. }\end{array}$ \\
\hline 3 & $\begin{array}{l}\text { Concept } \\
\text { Formation }\end{array}$ & $\begin{array}{l}\text {-The teacher asks the students to discuss the exploration results } \\
\text {-Students report the results of group discussions in front of the class about the } \\
\text { nature of the saline solution } \\
\text { - The teacher guides the students with inquiry questions } \\
\text { - Teachers help students to build concepts and make conclusions. }\end{array}$ \\
\hline 4 & $\begin{array}{l}\text { Application } \\
\text { concept } \\
\text { through } \\
\text { SSI case }\end{array}$ & $\begin{array}{l}\text { - Students are given SSI problems related to the nature of the saline solution } \\
\text { to be solved, i.e the impact of MSG on health. } \\
\text { - Students analyze SSI issues provided through group discussions } \\
\text { - Student present the results of the discussion }\end{array}$ \\
\hline 5 & Closure & $\begin{array}{l}\text {-Students summarize the nature of the derived salt solution from weak acids } \\
\text { and strong bases. } \\
\text {-Students reflect on the learning experience gained }\end{array}$ \\
\hline
\end{tabular}

\section{Instrument}

The research instrument consisted of treatment and measurement instruments. The treatment instruments were syllabus, lesson plan and students worksheet. This instrument was validated by two chemistry education lecturers. While the measurement instrument is a WIHIC questionnaire developed by Fraser, et al. (1996). This instrument was chosen because it was suitable for measuring the learning environment and has been successfully used in various countries such as Brunei, Canada, Korea, India, Singapore, USA, Taiwan and Indonesia (Aldridge et al., 2009). Beside that it also has been used in different subjects and level such as research of Allen \& Fraser (2007) on primary student in science subject and Ogbuehi \& Fraser (2007) on middle student in mathematic subject. The instrument consisted of 50 items of questions translated by the researcher into Indonesian and validated by two chemistry lecturers who understood the content and had the proficiency in English. The WIHIC instrument uses a Likert scale of 1-5 with criteria: always (5), often (4), sometimes (3), rarely (2) and never (1). There are seven aspects measured on the instrument such as students' cohesiveness; (2) teacher's support; (3) involvement; (4) investigation; (5) task orientation; (6) cooperation; and (7) equity. The reliability of WIHIC questionnaire calculated using Cronbach Alpha was 0.943. This value indicated that the WIHIC questionnaire had a very high reliability.

\section{Data Analysis}

The questionnaire scores in all three classes were tested for normality and homogeneity as prerequisite analysis test. Then, the data were analyzed by one-way ANOVA technique (one way ANOVA) followed by Post-Hoc LSD advanced test by using IBM SPSS 21.0 program at $95 \%$ confidence level $(\square=0,05)$ if the prerequisite test result were met. Meanwhile, if the prerequisite test was not met then the data is analyzed using nonparametric statistic Kruskall-Wallis H Test followed by Mann-Whitney test by using IBM SPSS 21.0 program at $95 \%$ confidence level $(\square=0,05)$. The test was conducted to find out whether there wasa difference of perception of 
learning between students who were studied with the POGIL model with SSI context, POGIL and conventional models. As in the previous explanation that this questionnaire has seven aspects that are measured. The analysis for each aspect is measured by using effect size to find out the effect of the instructional model in each aspect. For 3 sample groups, the measurement of effect size was determined based on the calculated eta square value using the SPSS 21.0 for Windows program. The value of the effect size is then defined according to the range in the following table:

Table 3 Effect size

\begin{tabular}{lc}
\hline Value $\left(\mathrm{eta}^{2}\right)$ & Effect Criteria \\
\hline $\mathrm{eta}^{2} \geq 0.14$ & Large \\
\hline $0.06 \leq \mathrm{eta}^{2}<0.14$ & Medium \\
\hline $0.01 \leq \mathrm{eta}^{2}<0.06$ & Small \\
\hline
\end{tabular}

\section{Result \& Discussion}

The data collected from the WIHIC questionnaire was analyzed for normality and homogeneity to determine the statistical methods used. The results of normality and homogeneity test are as follows.

Table 4 Result of normality and homogeneity test.

\begin{tabular}{lccccc}
\hline \multicolumn{1}{c}{ Group } & $\begin{array}{c}\text { Number of } \\
\text { Student }\end{array}$ & Mean & $\begin{array}{c}\text { Deviation } \\
\text { Standard }\end{array}$ & $\begin{array}{c}\text { Normality } \\
\text { Sig. (2-tailed) }\end{array}$ & Levene's test \\
\cline { 1 - 4 } Control & 28 & 3.57 & 0.449 & 0.175 & \multirow{2}{*}{0.111} \\
\cline { 1 - 5 } Experiment I & 29 & 3.98 & 0.344 & 0.098 & \\
\hline Experiment II & 28 & 4.08 & 0.371 & 0.200 & \\
\hline
\end{tabular}

Based on Table 4 it was known that the average experiment class was higher than the control class, the data was normally distributed and homogeneous. Normality and homogeneity of data was indicated by significance value $>0.05$. These results indicated that the prerequisite analysis test has been met, so the next analysis used parametric statistics. To test the hypothesis on students' perceptions of their learning environment, the average score was tested using one-way ANOVA test. ANOVA test results obtained significance value of 0.000 (sig. $<0.05)$. This means that in the three groups there were significant differences in student perceptions about the learning environment. This difference of perception showed that the learning model of POGIL with SSI was able to provide a positive learning environment for students. The positive difference was indicated by higher average score (see Table 4) compared to other classes. A positive learning environment in the classroom was crucial for meaningful learning to materialize (Ozerem \& Akkoyunlu, 2015). ANOVA test results continued with Post Hoc LSD test to know specifically the aspects of WIHIC where learning POGIL contextualized by SSI gave a significant difference in the perception of learning environment in students. The Post Hoc test results were presented in Table 5 .

Table 5 Post Hoc LSD Test Result

\begin{tabular}{llcc}
\hline \multicolumn{1}{c}{ Group (I) } & \multicolumn{1}{c}{ Group $(\mathrm{J})$} & Mean Difference (I-J) & Sig. (2-tailed) \\
\hline \multirow{2}{*}{ Control } & Experiment I & -0.507 & 0.000 \\
\cline { 2 - 4 } & Experiment II & -0.406 & 0.000 \\
\hline \multirow{2}{*}{ Experiment I } & Experiment II & 0.101 & 0.333 \\
\hline
\end{tabular}


Table 5 showed that there were significant differences of students' perceptions between students who were studied using POGIL with SSI, POGIL, and conventional models (Sig. <0.05), but did not show significant differences in student perception among students who studied using the POGIL with SSI model and the POGIL model (sig.> 0.05). The differences in the three groups were caused by different learning approaches. Different learning approaches would impact on different learning environments. This was because each learning approach had its own characteristics that wiwould be implemented in the stages of learning. The inquiry approach with the POGIL model in research groups I and II was process-oriented, thus encouraging the opportunity for students to be actively involved in learning (Hanson, 2006) than the control class, where students were only passive in the classroom. In addition, learning activities at POGIL use learning groups whereas conventional approaches do not.

Students who were studying in non-group or individually with a competitive environment would not experience intellectual challenges. The intellectual challenge of students in group learning occured when their theories and their perceptions were different, leading to disagreement. This disagreement encouraged them to actively seek information, think critically and tried to solve the problem given until they finally restructured their knowledge (Hanson, 2006). Active involvement of students in the classroom would improve students' motivation in learning (Liu et al., 2001) and their attitudes toward learning (Martin-Dunlop, 2012) so that their perceptions of the learning environment would be different. This was also reinforced by Lea et al. (2003) which stated that students believed the student-centered learning environment motivated them more.

Statistically, learning POGIL and POGIL berkonteks SSI did not show differences in student perception significantly. This is because in learning POGIL berkonteks SSI and POGIL students are both guided to actively involved in the group to be able to construct their own knowledge through group discussion. Most student activities in the class are the same, only a few different ones, namely the use of socioscientific issues (SSI) and contextual issues at the application stage in POGIL learning. At this stage students are given other problems to apply the concept they have gained. Students in both classes are likely to feel the same that both get challenges, although the nature of the problem is different. The same is also expressed by Eastwood et al. (2013) that although SSI is given explicitly on learning and is connected to science, this SSI is only part of the whole process of inquiry.

Although statistically did not show differences in students' perceptions between groups that were studied with the POGIL model with SSI context and POGIL, the mean score of students' perceptions in group I was higher than group II. This suggested that students who were taught by POGIL contextualized SSI experienced a different but insignificant learning environment than students who are taught by POGIL learning alone. This is possible because SSI as a context in the lesson enables students to actively engage in discussion activities. Students tended to be more motivated because the issues discussed related to the everyday life they had encountered in their environment (Feiranbend \& Eilks, 2010). This is reinforced by Rahayu (2016) stating that through relevant and familiar cases for students would assist students in visualizing abstract concepts to become more concrete and students could apply the knowledge they understood in the SSI debate.

In order to know the effect of learning POGIL with SSI context to the aspects of WIHIC in students, the score of student's responses grouped per aspect of WIHIC then tested the reliability and calculated effect sizenya. Below was the recapitulation of the relative results and the effect of the WIHIC students' score. 
Table 6 Effect size and Reliability for each Aspect of WIHIC

\begin{tabular}{lllccccc}
\hline \multicolumn{1}{c}{ Aspect } & $\begin{array}{l}\text { Effect } \\
\text { value } \\
\left(\mathrm{eta}^{2}\right)\end{array}$ & Criteria & Significance & Criteria & Reliability & Criteria \\
\hline Student Cohesiveness & 0.059 & Small & 0.083 & Not significance & 0.751 & High \\
\hline Teacher Support & 0.353 & Large & 0.000 & significance & 0.796 & High \\
\hline Involvement & 0.218 & Large & 0.000 & Significance & 0.765 & High \\
\hline Investigation & 0.226 & Large & 0.000 & Significance & 0.787 & High \\
\hline Task Orientation & 0.099 & Medium & 0.014 & Significance & 0.755 & High \\
\hline Cooperation & 0.044 & Small & 0.157 & Not significance & 0.778 & High \\
\hline Equity & 0.148 & Large & 0.001 & significance & 0.749 & High \\
\hline
\end{tabular}

Based on the data in table 6 above, the high reliability value in each aspect of WIHIC shows that this instrument is really capable of measuring what will be measured (Cresswel, 2012). POGIL with SSI has a large and significant influence on the aspects of teacher support, involvement, investigation and equity. There are several things that may cause this effect.

In the teacher support and equity aspect, the teacher acts as a facilitator in the learning that guides and directs the students to get the concept and each student is given equal opportunity to express his/her idea regardless of gender. In the involvement aspect, the use of study groups on the POGIL model with SSI context, could enable positive student interaction. Some research results also show that within the group, students can learn more, understand more or memorize more. Plus, they also feel better about themselves, their class and friends (Hanson, 2006). In addition to study groups, providing SSI at the application stage can create an SSI atmosphere where students integrate and apply basic scientific literacy such as being able to read science texts in various representational modes and have knowledge about science content (Norris and Phillips, 2003). The environment or atmosphere makes the students involved in negotiating their ideas to reach agreement as they discuss through the application of their understanding of existing science issues or topics (Nam \& Chen, 2017). The understanding in question is their understanding of what is considered to be good evidence and what is considered a good claim in this kind of environment for discussion (Duschl, 2008; Ryu \& Sandoval, 2012). In the investigation aspect, the use of SSI as an application stage in learning can increase students' curiosity, because the SSI problem presented by teachers is a rare fact/phenomena that they rarely know. Curiosity is very important in learning because students' curiosity is the basis of scientific discoveries (Rahayu, 2007). This curiosity will encourage/motivate students to engage in learning including investigative activities to find solutions to SSI problems (Pluck \& Johnson, 2011). In addition to curiosity, the motivation also arises because the use of SSI that can improve the significance of the learning they get because the content of the material they are learning is relevant to solve the problems that exist around them (Fletcher 2003; McRobbie \& Tobin, 1997).

In the aspect of task orientation, POGIL with SSI gives a moderate but significant influence. This can be explained because in the learning process, the teacher explicitly explains that there is a division of student tasks in the group, i.e the manager (ensuring all members are involved in problem solving and tasks completed on time), reflectors (commentators commenting on group dynamics), recorders (noting the group members' names at the beginning of the discussion and recording the results of the discussion) and the presenter (delivering the results of the discussion verbally to teachers and other friends) (Hale \& Mullen, 2009). This division is intended for the effort of obtaining concepts and solving problems of SSI can be effective (Trevathan \& Myers, 2013). In addition, the tasks in the form of SSI questions that they get require different ways of completion, compared to students who only get POGIL or conventional learning. Due to solving SSI problems, students are required to think critically about the issue with those with different views (Simmoneaux, 2008)

While on the aspect of cooperation and student cohesiveness, POGIL with SSI gives little influence and not significant. The insignificant results on the cooperation aspect mean that students in the three groups may work 
together both in groups and outside the group. This is possible because the activities covered in these two aspects can be realized in both control and experiment groups. For example, in a control class, although teachercentered learning, students can interact with their peers to ask questions or discuss issues they encounter during learning. Research conducted by Aldridge \& Fraser (1999) also showed that student cohesiveness aspects in students in two different countries, did not differ significantly.

\section{Conclusion}

Students' perceptions of their learning environment in the three classes showed significant differences. POGIL instruction both SSI-contextualized and non SSI-contextualized has a significant effect on students' perceptions of their learning environment towards students in the conventional class. However, the POGIL instructin with SSI did not have a significant effect on students' perceptions of their learning environment on POGIL only instruction. Among the seven aspects found in WIHIC, POGIL instruction with SSI gives a big and significant influence on the aspects of teacher support, equity, involvement and investigation. As for the aspect of task orientation, POGIL with SSI contexts provide a moderate but significant, while the aspect of cooperation and student cohesiveness showed little effect and not significant.

\section{Acknowledgements}

Our thanks to Ristekdikti (Directorate General of Higher Education) for funding us to do this research.

\section{References}

Abdullah, et al., 2013, The physical classromm learning environment. Proceeding of the $2^{\text {nd }}$ International Higher Education Teaching and Learning Conference 2013, Sarawak, Malaysia, December, pp. 80-85

Acat, B., \& Donmez, I., 2009, To compare student centred education and teacher centred education in primary science and technology lesson in terms of learning environments, Procedia Social and Behavioral Science, 1, 1805-1809.

Ahmad, C. N. C., Osman, K., \& Halim, L., 2012, Relationship betweem physical and psychosocial aspects in science laboratory environment, Social and Behavioral Sciences, 46, 1500-1505.

Aldrige, J. M., et al, 1999, Investigating Classroom Environments in Taiwan and Australia With Multiple Research Methods, The Journal of Education Research, 93(1), 48-62.

Aldridge, J., et al., 2009, Utilising learning environment assessments to improve teaching practices among inservice teachers undertaking a distance-education programme, South African Journal of Education, 29, 147-170.

Aldridge, J. M., \& Fraser, B. J., 2000, A cross-cultural study of classroom learning environments in Australia and Taiwan, Learning Environments Research,3, 101-134.

Allen, D., \& Fraser, B. J., 2007, Parent and student perceptions of the classroom learning environment and its association with student outcomes, Learning Environments Research, 10, 67-82.

Cresswell, J. W., 2012, Educational Research: Planning, Conducting, and Evaluating Quantitative and Qualitative Research Fourth Edition. (Boston : Pearson Education, Inc.

Den Brok, P., et al., 2010, Learning environments profiles of Turkish secondary biology classroom, Learning Environment Research, 13, 187-204.

Duschl, R., 2008, Quality argumentation and epistemic criteria. In S. Erduran \& M. Aleixandre (Eds.), Argumentation in Science Education, (Dordrecht: Springer), pp. 159-175

Eastwood, et al., 2013, Students' Participation in an Interdisciplinary, Socioscientific Issues Based Undergraduate Human Biology Major and Their Understanding of Scientific Inquiry, Research of Science Education, 43, 1051-1078.

Feiranbend, T. \& Eilks, I., 2010, Raising students' perception of the relevance of science teaching and promoting communication and evaluation capabilities using authentic and controversial socio-scientific issues in the Framework of climate change, Science Education International, 21(3), 179-196. 
Fletcher, A. 2003. Meaningful Student Involvement: A Guide To Inclusive School Change [PDF]. Date of Access 03/04/2018, https://soundout.org/wp-content/.../07/MSI_Guide_to_Inclusive_School_Change.pdf

Fraser, B. J., 1990, Individualised Classroom Environment Questionnaire, (Melbourne, Australia: Australian Council for Educational Research).

Fraser, B.J., 1994, Classroom and school climate. In Gabel, D. (Ed.), Handbook of Research on Science Teaching and Learning (pp. 493-541). Macmillan, New York.

Fraser, B., et al., 1996, Development, validation and use of personal and class forms of a new classroom environment questionnaire. Date of access 02/04/18. http://www.waier.org.au/forums/1996/fraser.html

Hale, D., \& Mullen, L. G., 2009, Designing process-oriented guided-inquiry activities: a new innovation for marketing classes, Marketing Education Review, 19(1), 73-80

Hanson, D. M., 2006, Instructor Guide to Process-Guided-Inquiry Learning,(Lisle: Pacific Crest).

Hanson, D. M., 2007, Designing Process-Oriented Guided-Inquiry Learning Activity. In S. W. Beyerlein \& D. K. Apple (Eds.), Faculty Guidedbook-A Comprehensie Tool for Improving Faculty Performance (Lisle : Pasific Crest), pp 281-284.

Hanson, D. M., \& Moog, R. S., 2007, Process Oriented Guided Inquiry Learning. In S. W. Beyerlein \& D. K. Apple (Eds.), Faculty Guidedbook-A Comprehensie Tool for Improving Faculty Performance (Lisle : Pasific Crest) pp 387-390.

Hofstein, A., Eilks, I., \& Bybee, R., 2011, Societal issues and their importance for contemporary science education - a pedagogical justification and the state-of-the-art in Israel, Germany, and the USA, International Journal of Science and Mathematics Education, 9(6), 1459-1483.

Johnson, B., \& Stevens, J. J., 2001, Exploratory and confirmatory factor analysis of the School Level Environment Questionnaire (SLEQ), Learning Environments Research, 4(3), 325-344.

Lea, S. J., et al., 2003, Higher education students' attitudes to student centred learning: beyond 'educational bulimia', Studies in Higher Education, 28(3), 321- 34.

Liu, et al., 2001, Web-Based Peer Review: The Learner as both Adapter and Reviewer, IEEE Transaction of Education, 44(3), 246-251.

Lorsbach, A.W., \& Basolo, F., 1998, Collaborating in the evolution of middle school science learning environment, Learning environment Research, 1, 115-127.

Maor, D., \& Fraser, B. J., 1996, Use of classroom environment perceptions in evaluating inquiry-based computer-assisted learning, International Journal of Science Education, 18, 401-421.

Martin-Dunlop, C.S., 2012, Prospective Elementary Teachers' Understanding of the Nature of Science and Perceptions of the Classroom Learning Environment, Research of Science Education, 43, 873-893.

McRobbie, C., \& Tobin, K., 1997, A social constructivist perspective on learning environment, International Journal of Science Education, 19(2), 193-208.

Nam, Y., \& Chen, C. C., 2017, Promoting Argumentative Practice in SocioScientific Issues through a Science Inquiry Activity, Mathematic Science and Technology Education, 13(7), 3431-3461.

Norris, S. P., \& Phillips, L. M., 2003, How literacy in its fundamental sense is central to scientific literacy. Science Education, 87(2), 224-240.

Ogbuehi, P. I., \& Fraser, B. J., 2007, Learning environment, attitudes and conceptual development associated with innovative strategies in middle-school mathematics, Learning Environments Research, 10, 101-114.

Ozzerem, A., \& Akkoyunlu, B., 2015, Learning Environments Designed According to Learning Styles and Its Effects on Mathematics Achievement, Eurasian Journal of Education Research, 61, 61-80.

Pluck, G. \& Johnson, H., 2011, Stimulating Curiosity to Enhance Learning. Education Science and Psychology, 2(19), 24-31

Reis, P., \& Galvao, C., 2009, Teaching controversial socio-scientific issues in biology and geology classes: A case study, Electronic Journal of Science Education, 13(1), 162-185.

Rentoul, A. J., \& Fraser, B. J., 1983, Development of a school-level environment questionnaire, The Journal of Educational Administration, 21(1), 21-39. 
Ruder, S. M., \& Hunnicutt, S. S., 2008, POGIL in chemistry courses at large urban university : A case study. In Process Oriented Guided Inquiry Learning (POGIL) by Moog, R., et al., ACS Symposium Series, (Washington : American Chemical Society), pp 133-147.

Rahayu, S., 2016, Mengembangkan literasi sains anak Indonesia melalui pembelajaran berorientasi Nature of Science (NOS), Paper presented in the Inaugural Speech of Professorship in Science at the Faculty of Mathematics and Natural Sciences, presented to the Senate Open Session of State University of Malang. Malang, 17 Mar 2016.

Rahayu, S., 2017, Promoting the 21st century scientific literacy skills through innovative chemistry instruction. Development of Chemical Education in 21 st Century Learning. Proceedings of the $2^{\text {nd }}$ International Seminar on Chemical Education (ISCE) 2017, Yogyakarta, Indonesia, September, pp. 1-9.

Rahmat, A., 2010, Kajian terhadap metode dan pendekatan pembelajaran Biologi di SMA: kesenjangan dalam pembelajaran di kelas, Jurnal Pengajaran MIPA, 15(1), 25-34.

Ryu, S., \& Sandoval, W. A., 2012, Improvements to elementary children's epistemic understanding from sustained argumentation. Science Education, 96(3), 488-526.

Sadler, T. D., 2004, Informal reasoning regarding socio-scientific issues: A critical review of research, Journal of Research in Science Teaching, 41, 513-536.

Sadler, T. D., 2008, Socioscientific issues in science education: labels, reasoning and transfer: Cultural Studies of Science Education, 4, 697-703.

Sadler, T. D., 2009, Situated learning in science education: socio-scientific issues as context for practice, Studies in Science Education, 45(1), 1-42.

Sadler, T. D., et al., 2007, What do students gain by engaging in socioscientific inquiry?, Research in Science Education, 37(4), 371-391.

Sadler, T. D., \& Zeidler, D. L., 2004, The morality of socioscientific issues: Construal and resolution of genetic engineering dilemmas. Science Education, 88, 4-27.

Sadler, T. D., \& Zeilder, D. L., 2005, Patterns of informal reasoning in the context of socioscientific decision making. Journal of Research in Science Teaching, 42(1), 112-138.

Simmoneaux, L., 2007, Argumentation in socio-scientific contexts. In S. Erduran \& M. P. Jimenez-Aleixandre (Eds.), Argumentation in Science Education: Perspectives from Classroom-based Research (Springer), pp 179199.

Slavin, R. E., 2006, Educational Psychology: Theory and Practice Eight Edition, (United States of America: Pearson Education Inc).

Taylor, D. \& Teddlie, C., 1992, Restructuring and the classroom: A view from a reform district, Paper presented at the annual meeting of the American Educational Research Association, San Francisco, CA, 20-24 April 1992.

Trevathan, J. \& Myers, T., 2013, Towards Online Delivery of Process-Oriented Guided Inquiry Learning Techniques in Information Technology Courses, Journal of Learning Design, 6(2), 1-11.

Walberg, H., 1968, Teacher personality and classroom environment Psychology in the schools, 5, 163-169.

Wolf, S. J., \& Fraser, B. J., 2008, Learning environment, attitudes and achievement among middle-school science students using inquiry-based laboratory activities, Research in Science Education, 38, 321-341.

Yahaya, J M., et al., 2016, College Students' Attitude toward Sexually Themed Science Content: A Socioscientific Issues Approach to Resolution. International Journal of Science Education, 38 (7), 1174-1196.

Zeidler, D. L., \& Nichols, B. H., 2009, Socioscientifiv issues: Theory and Practices, Journal of Elementary Science Education, 21(2), 49-58. 